\title{
ADAPTATION DIFFICULTIES OF A STUDENT WITH ASPERGER SYNDROME IN A POST-PRIMARY SCHOOL
}

\author{
TRUDNOŚCI ADAPTACYJNE UCZNIA Z ZESPOŁEM \\ ASPERGERA W SZKOLE PONADPODSTAWOWEJ
}

\begin{abstract}
Recently, we have observed an increase in the number of children diagnosed with Asperger's syndrome (autism spectrum disorder), hence the importance of increasing knowledge about the disorder and the ability to work with students with Asperger's syndrome. Children grow up, mature and move from primary schools to secondary schools, while teachers, educators, educators and school psychologists in secondary schools are not yet prepared to work with such students. If a child had little therapeutic support in childhood, it may be more difficult to cope with new situational factors such as the new school and environment. Asperger's syndrome is characterized by qualitative disturbances in the area of social interactions. Behavior patterns are limited and stereotyped, as are behavior and activity. Intellectual development is within the normal range, and often above average, the development of expressive speech and its understanding is also normal. Social development disorders can be characterized by five symptoms: difficulties in initiating and undertaking successful peer interactions, problematic behaviors related to aggression towards others and / or oneself, social anxiety disorders, uncontrolled specific behaviors and companions, and quite specific external appearance.
\end{abstract}




\section{STRESZCZENIE}

W ostatnim czasie obserwujemy wzrost liczby dzieci, u których diagnozuje się zespół Aspergera (zaburzenie ze spektrum autyzmu), stąd tak ważne jest poszerzanie wiedzy na temat tego zaburzenia oraz umiejętność pracy z uczniami z zespołem Aspergera. Dzieci rosną, dojrzewają i ze szkół podstawowych przechodzą do szkół ponadpodstawowych, natomiast nauczyciele, wychowawcy, pedagodzy i psycholodzy szkolni w szkołach średnich nie są jeszcze przygotowani do pracy z takimi uczniami. Jeśli w dzieciństwie dziecko miało niewielkie wsparcie terapeutyczne, może trudniej znosić nowe czynniki sytuacyjne, jakimi są nowa szkoła i otoczenie. Zespół Aspergera charakteryzuje się zaburzeniami jakościowymi w obszarze interakcji społecznych. Wzorce zachowania są ograniczone i stereotypowe, podobnie jak zachowania i aktywność. Rozwój intelektualny jest w granicach normy, a często powyżej przeciętnej, rozwój mowy ekspresyjnej i jej rozumienie jest również prawidłowe. Zaburzenia rozwoju społecznego mogą charakteryzować się pięcioma objawami: trudnościami w inicjowaniu i podejmowaniu udanych interakcji rówieśniczych, problematycznymi zachowaniami związanymi $\mathrm{z}$ agresją wobec innych i/lub siebie, zaburzeniami lękowymi o charakterze fobii społecznej, niekontrolowanymi, specyficznymi zachowaniami i współruchami oraz dość specyficznym wyglądem zewnętrznym.

KEYWORDs: Asperger Syndrome, difficulties in initiating and undertaking successful peer interactions, behavior related to aggression towards others and / or self, anxiety disorders of a social phobia nature, uncontrolled and specific behaviors and compassions, difficulties in adapting to a new situation.

SŁowa KLuczowe: zespół Aspergera, trudności w inicjowaniu i podejmowaniu udanych interakcji rówieśniczych, zachowania związane $z$ agresja wobec innych i/lub siebie, zaburzenia lękowe o charakterze fobii społecznej, niekontrolowane i specyficzne zachowania i wspótruchy, trudności adaptacyjne do nowej sytuacji.

\section{WPROWADZENIE}

W ostatnim czasie obserwujemy wzrost liczby dzieci, u których diagnozuje się zespół Aspergera (zaburzenie ze spektrum autyzmu). Stąd tak ważne jest poszerzanie wiedzy na temat tego zaburzenia oraz umiejętność pracy z uczniami z zespołem Aspergera (Borkowska, 2018, s. 81). Literatura dostępna na polskim rynku szczegółowo charakteryzuje to zaburze- 
nie oraz omawia pracę $\mathrm{z}$ dziećmi $\mathrm{w}$ wieku przedszkolnym i wczesnoszkolnym. Jednak jeśli chodzi o pracę z uczniem szkoły ponadpodstawowej, nie ma artykułów w Internecie czy pozycji książkowych na polskim rynku wydawniczym na ten temat. Trudno jest też znaleźć materiały do pracy $z$ adolescentem z zespołem Aspergera (dalej: ZA). Dzieci rosną, dojrzewają i ze szkół podstawowych przechodzą do ponadpodstawowych - trafiają do liceów i techników, gdzie wybierają określone kierunki kształcenia. Natomiast nauczyciele, wychowawcy, pedagodzy i psycholodzy szkolni w szkołach średnich nie są jeszcze przygotowani do pracy z takimi uczniami. Jeśli w dzieciństwie dziecko miało niewielkie wsparcie terapeutyczne lub było późno zdiagnozowane, może trudniej znosić nowe czynniki sytuacyjne, jakimi są nowa szkoła i otoczenie. To z kolei może utrudniać mu dostosowanie do nowej zmiany w życiu i poradzenie sobie z nią. Często prowadzi to do nowych trudności i nowych porażek. W szkole podstawowej uczeń z ZA często ma nauczyciela wspomagającego, natomiast w szkole ponadpodstawowej musi radzić sobie sam. Niestety jest to dla niego tak trudne, że może nie poradzić sobie z nową rzeczywistością i zacząć wycofywać się z relacji społecznych oraz nie wypełniać obowiązku szkolnego. Dlatego ważne jest, by uczeń z ZA miał w szkole osobę, która będzie mogła go wesprzeć i pomóc mu w nowej, kryzysowej sytuacji.

Dlatego zdecydowano się w niniejszym artykule zebrać i opisać pomocne i sprawdzone metody pracy $\mathrm{z}$ uczniem z zespołem Aspergera w szkole ponadpodstawowej. Artykuł jest zbiorem takich metod, przydatnych zwłaszcza nauczycielom pracującym z uczniami pierwszej klasy (a więc podejmującymi naukę w nowej szkole) na początku roku szkolnego. Informacje o przejawach radzenia sobie $z$ nową sytuacją oraz zmianach zachodzących w zachowaniu i rozwoju uczniów podczas nauki w nowej szkole pochodzą z obserwacji i pracy z tymi uczniami, realizowanej przez psychologa szkolnego, oraz z wywiadów z nauczycielami oraz rodzicami Basi, Darka, Jarka, Kamila, Jakuba, Jacka i Pawła (imiona uczniów zostały zmienione). Informacje uzyskane $\mathrm{z}$ obserwacji i wywiadów $\mathrm{z}$ nauczycielami i rodzicami były zbierane przez cały pierwszy rok szkolny edukacji w nowej szkole tych uczniów. Gromadzeniem informacji, obserwacją oraz pracą z uczniami z zespołem Aspergera zajmował się psycholog szkolny. 


\section{CO OZNACZA TERMIN „ZESPÓŁ ASPERgERA”?}

Kryteria diagnostyczne zespołu Aspergera opracowane zostały w 1992 r. przez WHO (World Health Organization, Światowa Organizacja Zdrowia) na podstawie ICD-10 oraz DSM-IV.

Według DSM-IV zespół Aspergera obejmuje całościowe zaburzenia rozwojowe. Charakteryzuje się on znacznym i utrzymującym się upośledzeniu interakcji społecznych, co wyraża się w powtarzających się zachowaniach i sztywnym trzymaniu się rutyny (Ehlers, Gilleberg, 1993, s. 1237-1350). Ten wzorzec zachowania zazwyczaj ujawnia się później niż inne uogólnione zaburzenia rozwoju, takie jak autyzm, ale mimo to dotyczy zasadniczego, długotrwałego upośledzenia psychicznego.

Według ICD-10 zespół Aspergera określa symbol F 84.5.

Podobnie jak w klasyfikacji DSM-IV, zespół ten został wyróżniony i włączony do grupy rozległych zaburzeń rozwojowych. Charakterystyczne dla zespołu Aspergera są zaburzenia jakościowe w obszarze interakcji społecznych. Wzorce zachowania u osób z tym zaburzeniem są ograniczone i stereotypowe, podobnie jak ich zachowanie i aktywność. Jednak rozwój intelektualny jest zawsze w granicach normy, a często nawet powyżej przeciętnej. Prawidłowy jest również rozwój mowy ekspresyjnej oraz jej rozumienie (Namysłowska, 2005, s. 127).

Kryteria DSM-IV i ICD-10 określają cechy charakterystyczne dzieci z zespołem Aspergera, które są dla nich specyficzne, a dzięki którym można wyodrębnić je z grupy dzieci z autyzmem klasycznym (Drała, Maciarz, 2012, s. 17).

Trudności w nawiązywaniu relacji społecznych oraz lęk społeczny determinują charakterystyczne formy zaburzeń zachowania na każdym etapie rozwoju (Tantam, 2000, s. 47-62). W miarę dorastania pogłębia się izolacja społeczna i osamotnienie. Psychologiczne konsekwencje wynikające z trudności emocjonalnych osób z ZA prowadzą do utrzymywania się u nich wysokiego poziomu lęku i rozwoju zaburzeń depresyjnych (Kim, 2000, s. 117-132), a także zachowań agresywnych w stosunku do siebie lub innych oraz zachowań aspołecznych. Osoby z zespołem Aspergera nie mają świadomości dotyczącej niepisanych reguł zachowań innych osób w sytuacjach społecznych, zachowują się w sposób sztywny, niezmienny i nie 
biorą pod uwagę reakcji osób z otoczenia (Bryńska, 2014, s. 54). W miarę rozwoju osoba z ZA może doświadczać różnego nasilenia objawów - od bardzo nieznacznych, subtelnych i prawie niezauważalnych, po tak bardzo nasilone, uniemożliwiające funkcjonowanie, że wymagają wsparcia specjalisty (Bryńska, 2014, s. 54).

Rokowania dotyczące samodzielności w życiu dorosłym osób z ZA zależą od poziomu uzyskanego wykształcenia, co z kolei wiąże się ze stopniem sprawności intelektualnej. Przy wysokiej inteligencji rokowania są dość optymistyczne (Namysłowska, 2005, s. 127).

\section{CHARAKTERYSTYKA UCZNIA SZKOEY PONADPODSTAWOWEJ Z ZESPOEEM ASPERGERA}

\section{Zachowanie}

Jeśli u dziecka zdiagnozowano zespół Aspergera, co zwykle następuje w wieku wczesnoszkolnym (czasem wcześniej), jest to diagnoza na całe życie. Dziecko rośnie i dojrzewa wraz z zaburzeniem, uczy się funkcjonować w społeczeństwie, poznaje zasady i normy w nim panujące. Gdy ma wsparcie rodziny, znajomych i terapeutów, wówczas wraz z wiekiem coraz lepiej sobie radzi w życiu społecznym, co nie znaczy, że zaburzenie zanika. Jednak kiedy wchodzi w wiek dorastania i „burzy hormonów”, nie rozumie tego, co się z nim dzieje, tak dobrze jak jego rówieśnicy. Nastolatkowi z ZA o wiele trudniej jest zrozumieć zmiany zachodzące w jego organizmie, trudno mu się do nich przyzwyczaić, podobnie jak do wszystkich zmian. Młody człowiek, któremu wraz z rozwojem „burzy się świat wewnętrzny”, a co za tym idzie świat zewnętrzny, dodatkowo w tym trudnym czasie idzie do nowej szkoły. Musi dostosować się do nowej rzeczywistości, w której wszystko jest inne - poczynając od nowej drogi do szkoły, nowej topografii samej szkoły, nowych zasad obowiązujących w nowej szkole, nowych przedmiotów, na nowych nauczycielach i nowych kolegach kończąc. Znowu musi poznawać nowe schematy, które znacząco różnią się od tego, co już zna i rozumie. Jest to ogromna rewolucja w poukładanym świecie nastolatka z ZA, który bezpiecznie czuje się tylko w środowisku znanym, poukładanym, a tym samym przewidywalnym. W nowym otoczeniu, jakim 
jest nowa szkoła, czuje się zagubiony, wystraszony, zdezorientowany, musi uczyć się nowych schematów, nowego porządku i tak naprawdę stworzyć swój świat na nowo, sam, bez opiekunów.

Osoby z ZA potrzebują w pewnym stopniu zachowania schematów, aby czuć się pewnie i odbierać świat jako stabilny. Wykazują niewielką elastyczność i spontaniczność, zainteresowanie zmianami pozostaje ograniczone. Typowe dla nich jest zachowywanie ustalonych zasad dotyczących np. wstawania i kładzenia się spać. Na zmiany w planie dnia lub na pominięcie pewnych rytuałów osoby ze spektrum autyzmu czasami reagują bardzo gwałtownie, w sposób zupełnie niezrozumiały dla osób postronnych. Opisywani uczniowie potrafili z pamięci podać swój plan każdego dnia w tygodniu, z dokładnością co do godziny. U młodzieży i dorosłych uwidacznia się zwiększone zdenerwowanie i napięcie emocjonalne, co może skutkować problemami w nowej szkole - zarówno edukacyjnymi, jak i społecznymi. Uczeń szkoły ponadpodstawowej w nowej sytuacji musi dostosować się do tych zmian albo nauczyć się większej elastyczności i akceptowania ich. W nowej szkole pomocny w tym zakresie może być wychowawca, pedagog, psycholog lub inny nauczyciel, który będzie wspierał ucznia z ZA. Nie jest on jednak nauczycielem wspomagającym, do którego do tej pory przyzwyczajony był uczeń i na którego mógł liczyć w każdej sytuacji szkolnej.

\section{Początek roku szkolnego w nowej szkole}

Wszyscy uczniowie, którzy 1 września pierwszy raz przekraczają progi nowej szkoły ponadpodstawowej, są zestresowani, ponieważ nie wiedzą, co ich czeka. Nie znają nauczycieli ani nowych kolegów, nie wiedzą jeszcze, jakie zasady panują w tej szkole, nie znają wymagań nauczycieli, a niektóre nazwy nauczanych przedmiotów (w technikum czy w szkole branżowej) są ,jak z kosmosu”. Jest to dla nich jedna wielka niewiadoma, nowe doświadczenie, a co za tym idzie - ogromny stres. Uczeń zakłada, że skoro wybrał tę szkołę, to musi ją skończyć, a więc przetrwać w tych nowych warunkach -4 lata w liceum albo 5 lat w technikum. Znów musi sobie wypracować dobrą pozycję w grupie rówieśniczej, dobrze zaprezentować się nauczycielom i w ogóle zaistnieć w nowej szkole. 
Dla ucznia z zespołem Aspergera nowa szkoła to jak dla nas inna planeta. Wszystkie schematy, których się nauczył i już całkiem swobodnie w nich funkcjonował, bo były znajome i już nie przerażały, przestają się sprawdzać, bo 1 września okazuje się, że wszystko jest inne. Dłuższa i bardziej skomplikowana jest droga do szkoły, zazwyczaj też większa jest sama szkoła, liczniejsi uczniowie i nauczyciele. Każdy nauczyciel ma inne zasady pracy, oceniania i inne wymagania, czasami bardzo odmienne od tych, jakie uczeń poznał w poprzedniej szkole. Nikt nie zna ucznia z ZA, i, co gorsza, on nikogo nie zna. Czasami zdarza się, że kojarzy kogoś z poprzedniej szkoły, ale nierzadko są to doświadczenia negatywne, co dodatkowo potęguje lęk. Do szkoły średniej trafiają 15-latkowie z już dużym bagażem doświadczeń, często odtrącani, wyśmiewani, a nawet $\mathrm{z}$ doświadczeniami znęcania się przez rówieśników. Często też mają doświadczenia bycia niezrozumianymi przez kolegów, nauczycieli, inne osoby dorosłe, a nawet przez rodzinę. Mają też różne doświadczenia z terapią, pomocą psychologiczno-pedagogiczną w poprzedniej szkole. Dlatego niektóre symptomy ZA mogą występować falami, czyli nasilać się np. w momencie stresu czy zmęczenia, ale po pewnym czasie wyciszają się lub zanikają całkowicie.

W nowej grupie każdy walczy o dobrą pozycję. Uczeń z ZA chciałby również przynależeć do grupy, być lubiany i akceptowany. Nie potrafi jednak do niej dołączyć, nie bardzo wie, jak ma się zachować w nowej sytuacji. Męczą go ludzie, hałas i tłum, im więcej ludzi, tym gorzej wśród nich się czuje, dlatego zachowuje się dziwnie. I już w pierwszym miesiącu w szkole przykleja się do niego łatka „dziwaka”. Zaczynają się pierwsze konflikty z rówieśnikami i uczeń z ZA zaczyna być poza grupą rówieśniczą, często staje się obiektem wyśmiewania, kpin i żartów. Wtedy bardzo pomocne dla ucznia z ZA jest złożenie przez rodziców, już na początku roku szkolnego, pisma o potrzebie kształcenia specjalnego; wówczas wychowawca, pedagog czy psycholog szkolny wiedzą, że należy wspomóc tego ucznia i zapewnić mu szczególną pomoc i wsparcie. Uczeń z ZA jest informowany, gdzie może przyjść po pomoc czy odpocząć w razie potrzeby. Może wydawać się to dziwne, ale dla osoby z ZA jest to bardzo ważne i pomocne, zwłaszcza w nowej sytuacji, w której się znalazł. Należy mu wszystko wytłumaczyć, pokazać, omówić, a czasem nawet rozpisać na kartce. Musi wiedzieć, że np. jeśli jest zdenerwowany, może 
przyjść do gabinetu pedagoga, psychologa szkolnego, pielęgniarki czy do biblioteki, by odpocząć, wyciszyć się i zebrać myśli; jeśli ma zadaną pracę do domu, musi zapisać sobie, co jest zadane, wykonać pracę w domu i przynieść na następne zajęcia odrobioną pracę domową.

Na początku roku szkolnego Darek miał zadaną prezentację, którą wykonał w domu w wymaganym terminie, ale ponieważ stwierdził, że jego praca nie jest dostatecznie dobra, nie przyniósł jej i dostał jedynkę. Mama starała się go przekonać, żeby oddał pracę nauczycielowi do oceny i poprawił jedynkę, jednak Darek odmówił kategorycznie. Psycholog szkolny również nie był w stanie przekonać go, choć używał różnych argumentów. Zaproponował, żeby Darek przygotował drugi raz prezentację, skoro tamta jest według niego zła. Tę propozycję uczeń również odrzucił, ponieważ twierdził, że nauczyciel nie pozwolił poprawiać tych prac. Inni uczniowie różnie rozumieją sformułowanie „nie można poprawiać prac” i próbują się jednak ratować, poprawiając pracę. Jednak uczeń z ZA widzi świat czarno-biało, czyli myśli: „zrobiłem pracę, ale jest zła, więc jej nie zaniosę, natomiast poprawić jej nie mogę i nie mam innej możliwości”. Choć może dziwne wydaje się takie rozumowanie, osoby z ZA tak postrzegają świat: zero-jedynkowo, albo coś jest albo nie - kropka.

Kolejny przykład z początku roku szkolnego: na pierwszych zajęciach nauczyciel powiedział wszystkim uczniom, że zwykle z jego przedmiotu ok. 80\% uczniów nie zdaje do następnej klasy. Nauczycielowi chodziło o zmobilizowanie uczniów do pracy od początku roku szkolnego. Wszyscy uczniowie z klasy nie bardzo się przejęli tym stwierdzeniem, natomiast Darek przez dwa tygodnie nie chciał chodzić do szkoły, schował się w swoim pokoju i nie wychodził z niego. Mamie powiedział, że nie zda do następnej klasy, bo tak powiedział mu nauczyciel, więc nie ma sensu chodzić do szkoły. Długo trzeba było tłumaczyć mu, co miał na myśli nauczyciel - w efekcie chłopiec poradził sobie $\mathrm{z}$ tym przedmiotem, otrzymał pozytywną ocenę na półrocze i na koniec roku szkolnego.

Dużą trudność sprawia uczniom z ZA na początku roku szkolnego podejście do nowego nauczyciela i zapytanie go o cokolwiek. W szkole, w której uczą się opisani uczniowie, psycholog szkolny zajmuje się sprawami uczniów z orzeczeniami, w tym i z ZA, jest ich „adwokatem” - chodzi 
do nauczycieli, tłumaczy ich zachowania i stara się pomóc nauczycielowi i uczniowi w trudnej sytuacji. Pomimo że w dzienniku elektronicznym są wskazania do pracy z danym uczniem, jeszcze raz tłumaczy nauczycielowi, co z danej sytuacji wynika i jak dobrze można by daną sytuację rozwiązać. Jest to dla psychologa mozolna praca, ale bardzo pomocna dla ucznia oraz nauczyciela i w efekcie przynosi dobre wyniki.

\section{CharaKterystyKa ZABURZEŃ SPEKTRUM AUTYZMU}

\section{Obszary zaburzeń osób z zespołem Aspergera}

- relacje społeczne

- komunikacja

- stereotypowe zachowania

W niniejszym artykule opisano jedynie pięć obszarów charakteryzujących zaburzenia rozwoju społecznego u osób z zespołem Aspergera.

\section{Objawy zaburzenia rozwoju społecznego osób z ZA w pięciu obszarach (Święcicka, 2010, s. 23-25)}

\section{- Trudności w inicjowaniu i podejmowaniu udanych interakcji rówie- śniczych}

Basia miała trudności w zainicjowaniu rozmowy z koleżanką z klasy, a bardzo jej na tym zależało. Psycholog wytłumaczył jej, jak ma to zrobić, jak się zachować, jak podejść do koleżanki, jak rozpocząć rozmowę, jakie tematy może poruszyć, kiedy pierwszy temat się wyczerpie. Wyposażona $\mathrm{w}$ informacje inicjowania i podtrzymywania rozmowy Basia poszła zaznajamiać się z nową koleżanką. Miała podejść do niej i prowadzić rozmowę przez całą przerwę śródlekcyjną - było to dla niej bardzo trudne zadanie. Na kolejnej przerwie miała przyjść do psychologa i powiedzieć, czy jej się powiodło. Basia wróciła, opowiedziała, o czym rozmawiała z koleżanką i jak spędziły wspólnie całą przerwę. Dziewczyna była bardzo zadowolona, bo odniosła swój mały sukces. Każdy sukces w życiu osoby z ZA jest bar- 
dzo ważny i pomaga poprawić własną samoocenę. Nawet uczniowi szkoły ponadpodstawowej, zwłaszcza na początku roku szkolnego, należy dawać szczegółowe instrukcje dotyczące kontaktów rówieśniczych, a wówczas jest szansa, że w późniejszym czasie uniknie konfliktów.

\section{- Problematyczne zachowania związane z agresją wobec innych i/lub siebie}

Wśród uczniów szkoły ponadpodstawowej z zespołem Aspergera zdarza się autoagresja, wyzywanie samego siebie czy obciążanie się winą, uderzanie siebie przedmiotami lub o przedmioty, a nawet planowanie samobójstwa. Obserwując uczniów, z którymi pracuje psycholog, nie zauważa się podobnych problemów zbyt często, jednak zdarzają się. Jarek, uczeń klasy maturalnej technikum, w połowie roku szkolnego był w złej formie psychicznej. Mówił, że jest bardzo zmęczony, bo ma dużo nauki: przygotowanie do egzaminu zawodowego, przygotowanie do matury, nauka pozostałych przedmiotów na bieżąco. Poza tym rówieśnicy wciąż go zaczepiali i mu dokuczali. W domu też nie było lepiej - rodzice mieli do niego pretensje, że za mało się uczy, ma złe oceny (według rodziców), no i za mało im pomaga $\mathrm{w}$ domu. Należy pamiętać, że uczniowie z ZA nie odróżniają tego, co jest ważniejsze i czego trzeba się w tej chwili uczyć, od tego, co jest mniej ważne i można poświęcić temu zadaniu mniej uwagi. Starają się robić wszystko na $100 \%$, a to bardzo wyczerpuje. Jarek po którejś zaczepce kolegów na przerwie stanął przy ścianie i uderzał w nią głową, bo już nie był $\mathrm{w}$ stanie poradzić sobie ze swoimi emocjami i w ten sposób rozładowywał napięcie.

\section{- Zaburzenia lękowe o charakterze fobii społecznej}

Uczniowie szkoły ponadpodstawowej mają bagaż co najmniej 10-letniego doświadczania bycia upokarzanymi przez rówieśników, a nawet bycia ofiarami znęcania się czy bójek i zastraszania. W związku z tymi przykrymi doświadczeniami u ucznia z ZA mogą pojawić się zaburzenia lękowe. Paweł dość często popadał w poważne konflikty z rówieśnikami we wcześniejszych latach. Te doświadczenia doprowadziły u niego do stosunkowo silnego zaburzenia lękowego. Mówił, że obawia się tych osób, które go 
krzywdziły, a teraz chodzą z nim do tej samej szkoły. Często zdarza się, że z lękiem współwystępują objawy somatyczne: przyspieszone bicie serca, bóle i zawroty głowy, mdłości, bóle brzucha, szum w uszach, pocenie się, niewyraźna mowa, stanowiące objawy silnego stresu.

\section{- Niekontrolowane, specyficzne zachowania i współruchy}

Możliwe przyczyny podobnych zachowań to nadruchliwość lub zaburzenia kompulsywne, połączone $\mathrm{z}$ wysokim poziomem lęku. Kamil radzi sobie ze zbyt dużym napięciem, chodząc w kółko, może dziwnie to wygląda, ale jemu to pomaga, jednak stara się to robić w odosobnieniu, żeby nie wzbudzać zainteresowania rówieśników. W szkole ponadpodstawowej widoczne są trudności w postaci niezgrabności ruchów. Uczniowie różnie radzą sobie na lekcjach wychowania fizycznego, ponieważ bardzo dużą trudność sprawia im skoordynowanie ruchów, np. nie potrafią złapać piłki rzuconej do nich i ich ruchy są niezgrabne, co wywołuje śmiech i kpiny rówieśników. Uczniowie opisywani w niniejszej pracy reagują różnie: Darek kategorycznie odmawia udziału w lekcjach WF-u, nawet nie przebiera się w strój sportowy, Jarek bierze udział w zajęciach i pomimo że koledzy się z niego śmieją, jest przygotowany do każdej lekcji wychowania fizycznego. Kilku uczniów ma zwolnienie lekarskie z WF-u, ale jest też taki uczeń - Kuba, który bardzo chętnie ćwiczy, a także bierze udział w grach drużynowych, np. w grze w siatkówkę. Jacek z kolei nie wyobraża sobie, żeby nie uczestniczyć w lekcji WF-u, dla niego byłaby to największa kara.

\section{- Dość specyficzny wygląd zewnętrzny}

Jarek jak na osobę nastoletnią ubiera się dość nietypowo, dzięki czemu wyróżnia się z tłumu, co oczywiście wzbudza śmiech rówieśników i zdziwienie dorosłych. Zawsze jest ubrany w koszulę, kamizelkę i marynarkę, spodnie od garnituru lub czarne dżinsowe. Jego ubranie zawsze jest czarne, czasami tylko wkłada ciemnoszarą koszulę. Nosi również dwa sygnety, ciemne okulary, kiedy jest zbyt jasno, a w chłodne i zimowe dni długi, czarny płaszcz i czarny kapelusz z szerokim rondem, a do tego teczkę. Ma również długie, związane gumką włosy. 


\section{TRUDNOŚCI Z OPANOWANIEM NOWYCH INFORMACJI I NOWEGO MATERIAEU W SZKOLE PONADPODSTAWOWEJ}

Christine Preißmann, dotknięta zespołem Aspergera psychoterapeutka i lekarz medycyny ogólnej, wspominając swoje życie w szkole średniej, pisze, że nauczyciele często nie rozumieją, dlaczego uczeń ze spektrum autyzmu osiąga $\mathrm{z}$ różnych przedmiotów nierówne wyniki. Ale też różne są jego wyniki z tego samego przedmiotu - zależnie od dnia. Twierdzą oni, że uczeń jest czasami mało skupiony i niezainteresowany lekcją, a czasem wręcz leniwy. Jednak jeśli nauczyciel potrafi zrozumieć ucznia i pomoże mu w poradzeniu sobie z trudną sytuacją, chociażby odpowiednio dla danego ucznia przygotuje środowisko, w którym ten uczy się i przebywa, uczeń może pokazać, że doskonale rozumie wykładany materiał, opanował go i jest w stanie wszystko powtórzyć (Preißmann, 2017, s. 148).

Ze względu na specyficzne zachowania osoba ze spektrum autyzmu bywa uznawana przez nauczycieli za niezbyt inteligentną, o czym niekiedy zostaje poinformowana bez ogródek. Może to być dla niej bardzo frustrujące, zwłaszcza gdy jest przekonana, że poradzi sobie z danym zadaniem. Niestety często spotyka się pedagogów, którzy w tych sprawach nie mają wystarczającego wyczucia i mogą wyrządzić uczniom ogromną krzywdę. Chociażby doprowadzić do wycofania się przez nich z relacji czy wręcz odmówienia kontynuowania nauki (Preißmann, 2017, s. 148). Kiedy podobny problem pojawiał się w opisywanej szkole, psycholog tłumaczył nauczycielowi, dlaczego ten uczeń zachowuje się w dziwny sposób, gdzie są granice jego możliwości, odwołując się często do zaleceń zawartych w orzeczeniu o potrzebie kształcenia specjalnego wydanego przez poradnię psychologiczno-pedagogiczną. W ten sposób psycholog starał się zażegnać konflikty i nieporozumienia na linii uczeń-nauczyciel.

Uczeń może źle rozumieć nie dość precyzyjnie podane polecenie albo w ogóle go nie zrozumieć; podobne sytuacje mogą zdarzyć się przy pisaniu wypracowań lub przy pracach domowych. Uczniowi z ZA największą trudność sprawia uchwycenie najważniejszych elementów tekstu. Natomiast ortografia i gramatyka nie sprawiają mu problemu, ponieważ panują tu stałe zasady, których można nauczyć się na pamięć. To samo dotyczy matematyki, z którą większość uczniów z ZA sobie radzi, jednak trudno- 
ści mogą sprawiać ćwiczenia tekstowe. Takie zadania mogą być trudne do rozwiązania, ponieważ uczeń z ZA nie umie odróżnić informacji ważnych od tych, które zostały umieszczone w tekście, by utrudnić rozwiązanie zadania. W takiej sytuacji pomocne jest wytłumaczenie nauczycielowi specyficznych cech i problemów danego ucznia, tak by lepiej mógł go zrozumieć i wiedział, jak sobie radzić i pomóc temu uczniowi w przyszłości. Nie powinno się pomijać również mocnych stron i szczególnych umiejętności ucznia z ZA, który jest dobrym obserwatorem i często ma bardzo dobrą pamięć. Warto tłumaczyć nauczycielom, by wydawali jasne i jednoznaczne polecenia, bez dwuznaczności i ironii, których uczeń z ZA kompletnie nie rozumie. Jeśli nie zrozumie polecenia, nie będzie w stanie go wykonać, i to nie z tego powodu, że nie jest inteligentny, jest leniwy czy nie nauczył się, tylko dlatego że nie jest dla niego jasne, co ma zrobić.

\section{TRUDNOŚCI ADAPTACYJNE UCZNIA Z ZESPOEEM ASPERGERA W NOWYCH WARUNKACH FUNKCJONOWANIA}

Przebywanie z innymi ludźmi, zwłaszcza nieznanymi i w większej grupie, jest dla osób ze spektrum autyzmu najbardziej stresującą sytuacją społeczną, jaką mogą sobie wyobrazić. W konsekwencji wielu z nich wycofuje się z aktywnego życia i unika kontaktów społecznych, koncentrując całą uwagę na swoich zainteresowaniach, by się zrelaksować. Co gorsza, zdarza się, że zamykają się w swoich domach i nie chcą podejmować kolejnych prób kontaktu. Większość z nich cierpi jednak z powodu samotności oraz izolacji (Preißmann, 2017, s. 63). Uczeń szkoły ponadpodstawowej z ZA nie potrzebuje aż tak intensywnego treningu umiejętności społecznych jak uczeń w młodszym wieku, jednak nieustannie potrzebuje niewielkiego korygowania jego zachowań na co dzień. Najbardziej zaś pomocy, kiedy przychodzi do nowej szkoły. Gdy wszystko jest nowe, niepoukładane, nieoswojone i przerażające, trzeba towarzyszyć uczniowi z ZA w poradzeniu sobie z trudnościami, pomagać w rozwiązywaniu problemów i dylematów oraz $\mathrm{w}$ razie potrzeby podpowiedzieć rozwiązania trudnej sytuacji. Kiedy uczeń z ZA już przyzwyczai się do nowej rzeczywistości, wtedy dobrze jest towarzyszyć mu w jego wędrówce do dorosłości podczas okresu szkolnego. 
Osoba z ZA cały czas potrzebuje motywacji do działania, zachęcania do podejmowania wciąż nowych wyzwań. Dzięki temu będzie osiągała małe sukcesy i być może powoli jej niska samoocena choć nieznacznie się podniesie. Ponieważ uczeń z ZA ma upośledzoną zdolność interakcji z innymi, co sprawia, iż jest postrzegany jako „dziwoląg” albo „kosmita”, każdy sukces jest dla niego bardzo ważny. Bardzo pomaga mu (a także jest pomocne $\mathrm{w}$ budowaniu relacji $\mathrm{z}$ nim), kiedy jest chwalony, komplementowany, podkreślane są jego umiejętności i zdolności. Każdy człowiek potrzebuje usłyszeć, że jest w czymś dobry, nawet jeśli sam to doskonale wie. Dużą wartością jest usłyszeć to jeszcze od kogoś. Każdy uczeń z ZA jest w czymś dobry. Może będzie mógł pomóc koledze zrozumieć partię materiału z jakiegoś przedmiotu, a to zachęci go do życia społecznego. Paweł jest najlepszy w klasie z elektryki, a jego koledzy pytają go o różne sprawy w tym zakresie i chłopiec dzięki temu zaczął funkcjonować w grupie, a nie obok niej, i przestał się bać kolegów - oswoił się. Pod koniec roku szkolnego w pierwszej klasie Paweł stwierdził, że w tej grupie czuje się dobrze i dogaduje się ze swoimi kolegami, mimo że początkowo bardzo się ich obawiał.

\section{PodsumoWANIE - WNIOSKI Z WEASNYCH OBSERWACJI}

\section{Jak pomóc uczniowi z zespołem Aspergera w nowej szkole i nowej rzeczywistości}

Nastoletnia osoba z ZA wie, czego potrzebuje, co potrafi, a z czym sobie sama nie poradzi. Zna swoje potrzeby, deficyty i siebie, jednak nie rozumie innych ludzi i relacji między nimi. Dlatego warto zapytać ucznia, co sprawia mu trudność, czego się obawia, co dla niego jest pomocne. Jeśli nie wie, co odpowiedzieć, można podpowiedzieć, podając konkretne przykłady.

Uczeń z ZA, jak każdy inny uczeń, musi nauczyć się samodzielnie funkcjonować w społeczeństwie i czas szkoły ponadpodstawowej to ostatni moment, kiedy ma zapewnioną bezpłatną pomoc (por. Jurewicz, 2011, s. 191-205). Potem, w dorosłym życiu, będzie musiał płacić za pracę terapeuty, który będzie mu tłumaczył sytuacje $z$ życia i podpowiadał sposoby radzenia sobie z nimi, jednak nikt nigdy nie załatwi za niego wszystkich jego spraw. 
Kiedy uczeń pozna osobę, która chce mu pomóc, a z czasem zacznie jej ufać, wówczas łatwiej będzie się porozumieć. On nauczy się tej osoby, a ta osoba nauczy się jego. Stanie się to łatwe dopiero wtedy, kiedy z całego serca będziemy chcieli pomóc uczniowi z ZA.

\section{Zanim zaczniesz pomagać}

Praca z uczniami z zespołem Aspergera jest ogromnym wyzwaniem i bywa bardzo trudna. Często są oni nierozumiani przez innych, choć fizycznie nie różnią się od swoich rówieśników. Ich niepełnosprawności nie widać. Jest im bardzo trudno obronić się przed negatywnym nastawieniem otoczenia oraz wykluczeniem, surową oceną. Sami nie potrafią się bronić, a tak naprawdę są to osoby bardzo wrażliwe, z olbrzymim potencjałem (Borkowska, 2018, s. 81). Trudności osób z ZA dla społeczeństwa są niewidoczne. Jeśli otrzymają pomoc w szkole, jest szansa, że poradzą sobie z nową sytuacją społeczną i będą w stanie ukończyć szkołę ponadpodstawową. Jednak pomoc i wsparcie są im potrzebne przez cały okres edukacji.

\section{Bibliografia}

Borkowska, A. (2018). Zrozumieć świat ucznia z zespołem Aspergera, Gdańsk: Wydawnictwo Harmonia, s. 81. ISBN 9788371344640.

Bryńska, A. (2014). Zespół Aspergera - kryteria diagnostyczne, obraz kliniczny. W: J. Komender, G. Jagielska, A. Bryńska, Autyzm i zespót Aspergera, Warszawa: Wydawnictwo Lekarskie PZWL, s. 54, 57. ISBN 9788320045208.

Carson, R.C., Butcher, J.N., Mineka, S. (2003). Uogólnione zaburzenia rozwojowe: Autyzm. W: R.C. Carson, J.N. Butcher, S. Mineka, Psychologia zaburzeń. Człowiek we współczesnym świecie, t. 2, Gdańsk: Gdańskie Wydawnictwo Psychologiczne, s. 828. ISBN 8389120178.

Drała, D., Maciarz, A. (2012). Dziecko autystyczne z zespołem Aspergera: studium przypadku, Kraków: Oficyna Wydawnicza „Impuls”, s. 17. ISBN 9788375875454.

Ehlers, S., Gillberg, Ch. (1993). The epidemiology of Asperger syndrome. A total population study, „Journal of Child Psychology and Psychiatry”, No. 34, s. 1237-1350, https://doi.org/10.1111/j.1469-7610.1993.tb02094.x.

https://polskiautyzm.pl/zespol-aspergera/ (dostęp: 22.05.2020). 
Kim, J.A. i in. (2000). The prevalence of anxiety and mood problems among children with autism and Asperger, „Syndrom Autism”, No. 4(2), s. 117-132, https://doi.org/ $10.1177 \% 2 \mathrm{~F} 1362361300004002002$.

Namysłowska, I. (red.) (2005). Psychiatria dzieci i młodzieży. F 84.5. Zespót Aspergera, Warszawa: Wydawnictwo Lekarskie PZWL, s. 126-128. ISBN 8320031966.

Preißmann, Ch. (2017). Zespół Aspergera, Sopot: Gdańskie Wydawnictwo Psychologiczne, s. 63, 148. ISBN 9788374897273.

Święcicka, J. (2016). Uczeń z zespołem Aspergera. Praktyczne wskazówki dla nauczycieli, Kraków: Oficyna Wydawnicza „Impuls”, s. 23-25. ISBN 9788380950849.

Tantam, D. (2000). Psychological disorder In adolescents and adults with Asperger syndrome, „Autism”, No. 4(1), s. 47-62. https://doi.org/10.1177\% 2F1362361300004001004. 